Ricardo Coelho Okida(a) Thiago Marchi Martins(b) André Luiz Fraga Briso(a)

(a) PhDs, Assistant Professors, Discipline of Restorative Dentistry; ${ }^{(b)}$ Specialist in Restorative Dentistry - School of Dentistry of Araçatuba, State University of São Paulo.

\section{In vitro evaluation of marginal leakage in bonded restorations, with mechanical or chemical-mechanical (Carisolv) removal of carious tissue}

\author{
Avaliação in vitro da infiltração marginal em \\ restaurações adesivas, com remoção mecânica \\ ou químico-mecânica (Carisolv) do tecido \\ cariado
}

\begin{abstract}
This study carried out an in vitro evaluation and comparison of the occurrence of marginal leakage in bonded restorations using mechanical or chemical-mechanical (Carisolv) removal of carious tissue. For that purpose, 40 extracted decayed human molars were divided into 4 groups: GI (burs + Prime \& Bond NT + TPH), GII (Carisolv + Prime $\&$ Bond NT + TPH), GIII (burs + SBMP + Z100) and GIV (Carisolv + SBMP + Z100). After accomplishment of the restorations and thermal cycling, the teeth were exposed to dye, sectioned and qualitatively evaluated. The results demonstrated that the system of removal of carious tissue did not influence the results of microleakage at any of the cavity margins. At dentinal margins, use of the Prime \& Bond NT + TPH restorative system allowed the occurrence of less microleakage than the SBMP + Z100 system.
\end{abstract}

Descriptors: Dental leakage; Dental caries; Dental restoration, permanent.

Resumo: Este estudo avaliou e comparou in vitro a ocorrência da infiltração marginal em restaurações adesivas, com a utilização de remoção mecânica e químico-mecânica do tecido cariado. Para a proposição, 40 dentes molares humanos extraídos cariados foram divididos em quatro grupos: GI (brocas + Prime \& Bond NT + TPH), GII (Carisolv + Prime \& Bond NT + TPH), GIII (brocas + SBMP + Z100) e GIV (Carisolv + SBMP + Z100). Após a execução das restaurações e termociclagem, os dentes foram expostos a corante, seccionados e avaliados qualitativamente. Os resultados demonstraram que o sistema de remoção de tecido cariado não influenciou a ocorrência de microinfiltração em quaisquer margens cavitárias. Nas margens dentinárias, a utilização do sistema restaurador Prime \& Bond NT + TPH demonstrou menor ocorrência de microinfiltração do que o sistema $\mathrm{SBMP}+\mathrm{Z} 100$.

Descritores: Infiltração dentária; Cárie dentária; Restauração dentária permanente.

\author{
Corresponding author: \\ Ricardo Coelho Okida \\ Faculdade de Odontologia de Araçatuba da \\ Universidade Estadual Paulista (UNESP) \\ Rua José Bonifácio, 1193 , Vila Mendonça, \\ Araçatuba - SP - Brazil \\ CEP: 16015-050 \\ E-mail: rcokida@foa.unesp.br
}

Received for publication on Jun 13, 2006

Sent for alterations on Oct 23, 2006

Accepted for publication on Dec 18, 2006 


\section{Introduction}

For years, it has been observed that, despite the efforts in adopting a preventive approach, dental caries is still the main factor leading to tooth loss. ${ }^{6}$ Thus, after the development of carious lesions, in most cases the dentist must perform surgical restorative procedures aiming at reestablishing the shape, function and esthetics of the teeth involved in the carious processes and especially restoring the health status. $^{6}$

In these situations, when more invasive procedures are needed, several types of cavity preparation and removal of carious tissue have been suggested and developed, especially due to fast technological evolution and to the several materials currently available. $^{6}$

Most professionals, however, still perform conventional removal of carious tissue using excavators and round burs at low speed. Notwithstanding, a chemical-mechanical system has been recently developed as an option for the removal of this tissue, whose main advantage is to provide a less traumatic resource for the patient and allow more selective removal of the carious tooth structure. ${ }^{1}$

The utilization of chemical substances for disclosure and removal of carious tissue was initiated in 1979 with Fusayama ${ }^{8}$, who employed a dye composed of $0.5 \%$ basic fuchsin in propylene glycol on carious lesions to observe infected dentin. However, due to the carcinogenic potential of this substance, a dye composed of $1 \%$ acidic red in propylene glycol was adopted, which theoretically would disclose only the dentin that should be removed. ${ }^{8}$

Later, Maltz et al. ${ }^{16}$ (1998) demonstrated that dyes such as $1 \%$ acidic red in propylene glycol have affinity with areas with lower mineral concentration, such as the dentinoenamel junction, and deep circumpulpar dentin, and with areas with a high degree of porosity, such as white spot lesions. ${ }^{15}$ For that reason, the utilization of these dyes has not been effective for the identification of only infected dentin; rather, they also stain areas of intact dentin.

More recently, the current stage of alternatives for the disclosure and removal of carious tissue comprises a new chemical-mechanical system for caries removal called Carisolv, which has been presenting good outcomes compared to the conventional system. ${ }^{9}$ This product has been the subject of many histotomographic studies that revealed that the intact dentinal structure is not significantly affected by its utilization, since the penetration of Carisolv into intact dentinal tubules is not greater than $50 \mu \mathrm{m}$ in depth. ${ }^{9}$ Similarly, while testing microtensile bond strength, Burrow et al. ${ }^{3}$ (2003) observed that the product does not significantly affect the bonding of adhesive restorative materials to dentinal tissue, as also observed by Erhardt et al. ${ }^{7}$ (2004).

However, considering the increased utilization of adhesive restorative techniques, there is a lack of studies in the literature relating the utilization of chemical-mechanical systems with the occurrence of marginal leakage in restorations.

Thus, the present study evaluated the occurrence of microleakage in Class $\mathrm{V}$ cavities, with cervical margins in dentin/cementum and occlusal margins in enamel, prepared by the chemical-mechanical method (Carisolv) or by the conventional method for the removal of carious tissue, and restored with different adhesive restorative materials currently employed.

\section{Material and Methods}

Before carrying out the experimental part of the study, the project was submitted to and approved by the Institutional Review Board of the Dental School of Araçatuba, UNESP (Process n. 2001-00631). The study was conducted on 40 human teeth presenting caries at the buccal and lingual cervical thirds, extracted for periodontal reasons. The teeth were obtained from emergency dental services, dental offices and basic health centers in the city of Araçatuba, SP, Brazil, and were extracted for reasons not related to the study. After extraction, the surfaces of the teeth were cleaned with scalers and a n. 11 blade for the removal of calculus and remnants of the periodontal ligament. They were then stored in a $2 \%$ formalin solution $(\mathrm{pH} 7.0)$ for 14 days, and subsequently stored in saline solution.

Then the teeth were randomly divided according to the study groups, and restored following the sequence described below. 


\section{Group I}

In this group, the carious tissue was removed by the conventional method, i.e. beginning with excavators and then followed by smooth round burs with sizes adequate to the extension of the carious lesion, at low speed. For observation of the complete removal of carious tissue, the clinical-tactile criterion was adopted, and the desirable characteristic was the achievement of a remaining dentin resistant to attrition and to the penetration of a dental probe. Then, prophylaxis was performed with pumice and water with the aid of a rubber dam at low speed. After washing and drying, acid etching was performed with $37 \%$ phosphoric acid gel (Dentsply Caulk, Petrópolis, RJ 90915, Brazil). Application of the adhesive system Prime \& Bond NT (Dentsply Caulk, Petrópolis, RJ 90915, Brazil) was then carried out following the manufacturer's instructions. After obtaining shiny dentin and enamel surfaces, the cavity was considered ready to receive the restorative material.

The cavity was then filled with increments of composite resin TPH (Dentsply Caulk, Petrópolis, RJ 90915, Brazil) which were light-cured for 40 seconds each with a light intensity of $450 \mathrm{~mW} / \mathrm{cm}^{2}$.

\section{Group II}

In this group, the infected tissue was removed with the chemical-mechanical system Carisolv (Medi Team, Dentaluveckling I, Goteborg, AB). This system is available in two plastic syringes, and its activation is initiated by the contact between the gels in each syringe. This step was performed immediately after onset of treatment. The mixture was taken to the carious lesion with the aid of its proper instruments and the product was allowed to act for 30 seconds. After staining of the infected tissue was observed, it was removed with a manual cutting instrument supplied by the manufacturer. The product was applied until complete removal of the infected tissue, as clinically demonstrated by the absence of staining of the dentinal tissue secondary to application of the dye supplied in the product. In this situation, the Carisolv gel remains clear because it no longer reacts with the infected tissue.

The restorative procedures were then performed as described for Group I.

\section{Group III}

For this group, the infected tissue was removed by the conventional method, as described for Group I, yet the adhesive system employed was Scotchbond Multi Purpose (3M Dental Products, Irvine, CA 92614), whose application technique also followed the manufacturer's instructions. The adhesive system was then light-cured for 20 seconds and composite resin Z100 (3M Dental Products, Irvine, CA 92614) was inserted as described for the other groups.

\section{Group IV}

In this group, Carisolv was also employed for the removal of carious tissue, and the product was applied as described for Group II. The restorative procedures were the same as described for Group III.

After completion of the restorations, the specimens were kept for 24 hours in a FANEM oven (model $315 \mathrm{SE}$ ) at $37^{\circ} \mathrm{C}$, and then finished and polished with the Soflex Pop-On system (3M Dental Products, Irvine, CA 92614). Then the specimens were submitted to 100 thermal cycles at $5^{\circ} \mathrm{C}$ and $55^{\circ} \mathrm{C}( \pm 2)$ and received two coats of nail enamel; only the interface to be evaluated was kept exposed. The specimens were then immersed in $2 \%$ basic fuchsin for 8 hours, washed in tap water for 10 minutes, individually mounted onto acrylic resin blocks and sectioned in the buccolingual direction with a Buehler metallographic cutter (model Isomet), under water cooling, to produce two sections, which were then evaluated.

Evaluation of the degree of marginal leakage was performed with the aid of a stereoscopic magnifying glass Stemi SU11 (Zeiss) with $16 \mathrm{X}$ magnification; scores 0 to 3 were assigned to the margins in enamel and dentin/cementum, as described in Chart 1. The data were plotted and submitted to statistical analysis by the Mann-Whitney test at 5\%.

\section{Results}

Table 1 reveals that, for cavity margins in enamel, both the technique for removal of carious tissue and the restorative system did not influence the occurrence of microleakage, with statistical similarity between all study groups. 
Chart 1 - Evaluation of the degree of marginal leakage in enamel/dentin.

\begin{tabular}{c|l|l}
\hline Score & Degree & \multicolumn{1}{c}{ Marginal leakage } \\
\hline 0 & Absent & Absence of dye at the tooth/restoration interface \\
\hline 1 & Mild & Dye penetration at the tooth/restoration interface up to half of the distance between the cavosurface angle and the axial wall \\
\hline 2 & Moderate & Dye penetration at the tooth/restoration interface up to more than half of the occlusal wall in enamel and dentin \\
\hline 3 & Severe & Dye penetration at the tooth/restoration interface, reaching the axial wall \\
\hline
\end{tabular}

Table 1 - Comparison between the medians obtained for the occurrence of microleakage at the enamel margins.

\begin{tabular}{l|c|c|c|c|c|c}
\hline & \multicolumn{3}{|c|}{ Conventional } & \multicolumn{3}{c}{ Carisolv } \\
\hline & Median & Min. & Max. & Median & Min. & Max. \\
\hline TPH & $0.00 \mathrm{Aa}$ & 0.00 & 1.00 & $0.00 \mathrm{Aa}$ & 0.00 & 1.00 \\
\hline Z100 & $0.00 \mathrm{Aa}$ & 0.00 & 1.00 & $0.00 \mathrm{Aa}$ & 0.00 & 1.00 \\
\hline
\end{tabular}

Medians followed by similar letters (capital letters in lines and lower case letters in rows) are not statistically different according to Mann-Whitney's test $(p>0.05)$. Min. $=$ Minimum, Max. $=$ Maximum.

With regard to the cavity margins in dentin, restorations performed with TPH and Z100 were not influenced by the technique for removal of carious tissue. However, the TPH restorative system provided better control of the occurrence of microleakage with both types of preparation, as revealed by comparison of the medians presented in Table 2.

\section{Discussion}

The search for a conservative manner of removing carious tissue has been investigated by several authors since the conventional approach using burs allows a fast procedure, yet may lead to unnecessary wear of tooth structure, due to the effective cutting of these instruments, consequently weakening the remaining tooth structure. ${ }^{2,4,5,19,21,22}$

According to Inaba et al. ${ }^{11}$ (1995), Carisolv, which is made of sodium hypochlorite $(\mathrm{NaOCl})$, is a proteolytic agent that allows effective removal of organic components, leading to rupture of hydrogen bonds in the dentinal collagen fibers previously degraded by the demineralization secondary to the carious process. These authors further state that this rupture would soften this tissue and consequently reduce the pressure required for removal by attrition, ${ }^{19}$ a characteristic of the ideal action of instruments especially developed for utilization
Table 2 - Comparison between the medians obtained for the occurrence of microleakage at the dentin/cementum margins.

\begin{tabular}{l|c|c|c|c|c|c}
\hline & \multicolumn{3}{|c|}{ Conventional } & \multicolumn{3}{c}{ Carisolv } \\
\hline & Median & Min. & Max. & Median & Min. & Max. \\
\hline $\mathrm{TPH}$ & $0.50 \mathrm{Ab}$ & 0.00 & 1.00 & $0.00 \mathrm{Ab}$ & 0.00 & 1.00 \\
\hline $\mathrm{Z100}$ & $1.00 \mathrm{Aa}$ & 0.00 & 2.00 & $1.00 \mathrm{Aa}$ & 0.00 & 2.00 \\
\hline
\end{tabular}

Medians followed by similar letters (capital letters in lines and lower case letters in rows) are not statistically different according to Mann-Whitney's test $(p>0.05)$. Min. $=$ Minimum. Max. $=$ Maximum.

with this product. This undoubtedly allows better control of wear when compared to removal with burs following the conventional technique, in which large amounts of dentin are removed in blocks, with higher possibility of pulp exposure. ${ }^{1}$

It should be highlighted that the interaction of the chloride present in the product with collagen does not occur in mineralized tissues. The chemicalmechanical removal, thus, may not be applied in incipient lesions, since the mineral components protect the collagen fibers from the action of sodium hypochlorite, assigning selectivity to this technique. ${ }^{1}$

Fusayama $^{8}$ (1979) made use of similar solutions and proposed the removal of only infected dentin, which could not be remineralized, allowing preservation of the inner layer, which is not contaminated. ${ }^{8,10}$ However, more recently, Maltz et al. ${ }^{16}$ (1998) conducted histological and bacteriological analyses and demonstrated that chemical-mechanical removal does not assure complete absence of microorganisms in the remaining dentin. Also, according to Kidd et al. ${ }^{14}$ (1993), morphological and ultrastructural analyses of intact teeth demonstrated that the dyes stain areas with high degree of porosity, such as areas with limited organic content (lesions without cavities) and areas with a large amount of organic matter (dentinoenamel junction and circumpulpar dentin). Thus, 
the chemical-mechanical removal in deep carious lesions might increase the risk of pulp exposure.

Considering these observations as to the utilization of Carisolv, the formation of a uniform hybrid layer in all cavity walls becomes fundamental to allow an hermetic sealing of the tooth/restoration interface and thus eliminate the substrate, so that any possible remaining bacteria would reduce their metabolism and become inactive. ${ }^{23}$

It should be highlighted that failure in the interaction between adhesive system and tooth substrate yields poor marginal sealing with consequent microleakage, which may lead to early loss of the restoration, postoperative sensitivity, discoloration, marginal deterioration and secondary caries, ultimately leading to displacement of the restoration and pulp damage. ${ }^{20}$

Within this context, after accomplishment of the cavity preparation and removal of the carious tissue, especially using burs, formation of a layer of organic and mineral debris called smear layer occurs. Its removal is an important step to allow better interaction with most hydrophilic adhesive systems currently adopted. ${ }^{17}$ On the other hand, when manual cutting instruments are used, the evidence demonstrates that this layer is not formed and the surface treatments are applied directly on the dentinal tissue. ${ }^{18}$

The results of the microleakage test revealed no statistically significant difference between the materials evaluated at the enamel margins, regardless of the technique employed for removal of the carious tissue (Table 1), which once again demonstrates the effectiveness of enamel acid etching on the sealing achieved in restorations with enamel margins, as also observed in other studies ${ }^{5,23}$. As for the decayed tissue removal, the procedures used did not influence the occurrence of microleakage in any margin, being the restorative system the limiting factor of restoration performance.

However, with regard to the margins in dentinal tissue, the groups restored with the Prime \& Bond NT adhesive system and TPH composite resin presented better outcomes when compared to the groups restored with the Z100 composite resin system.

The similar performance of both the conventional and chemical-mechanical techniques associated to the difference in the performance of restorations in dentinal tissue suggest that more importance should be assigned to the restorative system and cavity margins than to the method of removal of carious tissue. Moreover, it can be assumed that the use of phosphoric acid by the evaluated restorative systems produced similar results in terms of hybrid layer formation, with or without the presence of smear layer.

According to Jacobsen, Soderholm ${ }^{13}$ (1998), acetone-based adhesives present a higher diffusion ability and display more effective penetration of the adhesive into the dentinal structure, either exposed to hypochlorite or not.

On the other hand, Inai et al. ${ }^{12}$ (1998) assigned the results observed in dentin with the Prime \& Bond 2.1 system to the presence of a phosphoric acid ester in its composition, which would allow a better interaction between the phosphate radicals and the calcium ions in dentin, and this substance is not found in the Scotchbond Multi Purpose adhesive system. The authors further report that, even after removal of collagen by $\mathrm{NaOCl}$, the performance of the Prime \& Bond adhesive was better compared to that of Scotchbond Multi Purpose, whose primer contains water and alcohol.

Thus, the present study is expected to contribute to evaluate and compare the conventional and chemical-mechanical methods for removal of carious tissue, prior to the accomplishment of the restorative procedure. The indication and utilization of Carisolv as a means for the removal of carious tissue has presented encouraging outcomes; however, further studies and a strict analysis of the viability of its routine utilization are recommended. On the other hand, the conventional method for the removal of carious tissue, in addition to being an easy one, still provides favorable results from a biological standpoint.

\section{Conclusions}

Based on the obtained results and according to the methodology employed, the following conclusions could be drawn:

1. The technique for removal of carious tissue did not influence the degree of marginal leakage for margins in enamel and dentin/cementum. 
2. The restorative system did not influence the occurrence of microleakage in the enamel margins.

3. The restorative system comprising the Prime \& Bond NT adhesive and the TPH composite resin

\section{References}

1. Bianchi S, Ciuffreda M, Poggio C, Piacontini C, Paroli R. Sistema Caridex per la rimozione della carie: sperimentazione clinica. Dent Cadmos. 1989;57(12):46-52.

2. Black GV. Operative dentistry. Chicago: Medical Dental; 1908.

3. Burrow MF, Bokas J, Tanumiharja M, Tyas MJ. Microtensile bond strengths to caries-affected dentine treated with Carisolv. Aust Dent J. 2003;48(2):110-4.

4. Çehreli ZC, Yazici AR, Akca T, Özgünaltay G. A morphological and micro-tensile bond strength evaluation of a singlebottle adhesive to caries-affected human dentine after four different caries removal techniques. J Dent. 2003;31(6):42935.

5. Conceição EN. Dentística: saúde e estética. Porto Alegre: ARTMED; 2000.

6. Cortes O, Garcia C, Perez L, Perez D. Marginal microleakage around enamel and cementum surfaces of two compomers. J Clin Pediatr Dent. 1998;22(4):307-10.

7. Erhardt MC, Amaral CM, de Castro AK, Ambrosano GM, Pimenta LA. In vitro influence of Carisolv on shear bond strength of dentin bonding agents. Quintessence Int. 2004;35(10):801-7

8. Fusayama T. Two layers of carious dentin: diagnosis and treatment. Oper Dent. 1979;4(2):63-70.

9. Gallo J, Xu X, Burgess JO, Re GJ. Dentin bond strength of three composite resins using five adhesives [abstract]. J Dent Res. 1988;77:945.

10. Haak R, Wicht MJ, Noack MJ. Does chemomechanical caries removal affect dentine adhesion? Eur J Oral Sci. 2000;108(5): 449-55.

11. Inaba D, Duschner H, Jongebloed W, Odelius H, Takagi O, Arends J. The effects of a sodium hypochlorite treatment on demineralized root dentin. Eur J Oral Sci. 1995;103(6):36874.

12. Inai N, Kanemura N, Tagami J, Watanabe LG, Marshal SJ, Marshal GW. Adhesion between collagen depleted dentin and dentin adhesives. Am J Dent. 1998;11(3):123-7. was more effective to control microleakage than the system comprising the SBMP adhesive and the Z100 resin for margins in dentinal tissue.

13. Jacobsen T, Soderholm KJ. Effect of primer solvent, primer agitation, and dentin dryness on shear bond strength to dentin. Am J Dent. 1998;11(5):225-8.

14. Kidd EA, Ricketts DN, Pitts NB. Occlusal caries diagnosis: a changing challenge for clinicians and epidemiologists. J Dent. 1993;21(6):323-31.

15. Kubo S, Li H, Burrow MF, Tyas MJ. Nanoleakage of dentin adhesive systems bonded to Carisolv-treated dentin. Oper Dent. 2002;27(4):387-95.

16. Maltz M, Henz SL, Volkweis A, Campos CS. Morphological and ultrastructural evaluation of the specificity of caries detector dye in the identification of carious dentine [abstract]. Caries Res. 1998;32(4):294.

17. Mertz-Fairhurst EJ, Call-Smith KM, Shuster GS, Williams JE, Davis QB, Smith CD et al. Clinical performance of sealed composite restorations placed over caries compared with sealed and unsealed amalgam restorations. J Am Dent Assoc. 1987;115(5):689-94.

18. Naressi SCM. Comparação da infiltração marginal de restaurações adesivas empregando instrumento rotatório e um sistema químico-mecânico na remoção do tecido cariado [Tese de Doutorado]. São José dos Campos: Faculdade de Odontologia da UNESP; 1999.

19. Petruzillo MA, McNierney HD. Chemomechanical caries removal system in pediatric dentistry. NY State Dent J. 1998;54(2):29-32.

20. Pinheiro SL, Aoki CMB, Mendes FM, Bengston AL. Avaliação morfológica da dentina após diferentes métodos de remoção do tecido cariado. Rev Assoc Paul Cir Dent. 2004;58(5):363-8.

21. Robbins A, Ragan MR. Dentist's influence on patient demand for local anesthesia with a chemomechanical system. J Prosthet Dent. 1988;59(2):142-5.

22. Toi CS, Bönecker M, Cleaton-Jones PE. Mutans streptococci strains prevalence before and after cavity preparation during atraumatic restorative treatment. Oral Microbiol Immunol. 2003;18(3):60-4.

23. Yip HK, Beeley JA, Stevenson AG. Mineral content of the dentin remaining after chemomechanical caries removal. Caries Res. 1995;29(2):111-7. 